DOI: https://doi.org/10.34069/AI/2022.49.01.7

How to Cite:

Tokarchuk, L., Pereverzyeva, O., Volkova, N., Yanitska, I., \& Bodnaruk, M. (2022). Constitutional principles of protection of family rights and interests of the child in civil proceedings. Amazonia Investiga, 11(49), 61-68. https://doi.org/10.34069/AI/2022.49.01.7

\title{
Constitutional principles of protection of family rights and interests of the child in civil proceedings
}

\author{
Конституційні засади захисту сімейних прав та інтересів дитини у цивільному \\ судочинстві
}

Received: November 5, 2021

Abstract

In today's society, paradigms and models of child-rearing, values, and opportunities of parents, competent authorities, and the court to ensure the rights of the child are changing. Most states have identified the protection of family rights and interests of the child, the avoidance of violence against the child, the prohibition of bullying, etc. among the priority areas of state policy. It is important to analyze the constitutional principles of protection of family rights and the concept "the best interests of the child" in civil proceedings, because it is the court that the legislator has the broadest powers in this area, compared to other jurisdictions. The work aims to study the guiding constitutional principles based on which the court can protect the family rights and interests of the child. The research methodology consists of general theoretical and special scientific methods, namely: hermeneutic, system-structural, structural-functional, historical-legal, comparative-legal, and formal-logical. As a result of the study, the mechanisms of the best possible protection of children's rights by the
Accepted: January 6, 2022

\author{
Written by: \\ Liudmyla Tokarchuk ${ }^{21}$ \\ https://orcid.org/0000-0001-9691-148X \\ Olga Pereverzyeva ${ }^{22}$ \\ https://orcid.org/0000-0002-4857-6469 \\ Nataliia Volkova ${ }^{23}$ \\ https://orcid.org/0000-0003-4346-1862 \\ Inna Yanitska ${ }^{24}$ \\ https://orcid.org/0000-0002-4729-9076 \\ Mykola Bodnaruk ${ }^{25}$ \\ https://orcid.org/0000-0001-7386-465X
}

\footnotetext{
${ }^{21}$ Doctor of Legal Sciences, Dean of the Faculty of Economics and Law of I. I. Mechnikov Odessa National University, Ukraine.

${ }^{22} \mathrm{Ph} . \mathrm{D}$, Senior Researcher of the Department of International Law and Comparative Law of the Institute of State and Law of V.M. Koretsky, National Academy of Sciences of Ukraine, Ukraine.

${ }^{23}$ Ph.D., Associate Professor of the Department of Civil Procedure of National University «Odesa Law Academy», Ukraine.

${ }^{24} \mathrm{Ph}$.D., Associate Professor of the Department of Civil Procedure of National University «Odesa Law Academy» (Ukraine).

${ }^{25}$ Doctor of Legal Sciences, Associate Professor, Professor of the Department of Private Law, Yuri Fedkovych Chernivtsi National University (Ukraine).
} 
courts were analyzed. An analysis of current case law, including the case-law of the European Court of Human Rights, concluded that today courts and other competent bodies pay considerable attention to analyzing "how a child will be better" and make informed decisions and, if necessary, correct previous mistakes.

Keywords: constitutional principles, civil proceedings, the best interests of the child, child, family rights and interests.

\section{Introduction}

In the system of legal guarantees that ensure the exercise of any rights, the main thing is the protection through which the restoration of the situation that existed before the violation, prevention, and cessation of illegal actions is achieved. Safety of family rights and legally protected interests is the most significant guarantees for the existence of these rights and interests. This is since the rights and interests in any sphere of public life are not always exercised without hindrance. The protection of subjective rights is realized in the manner prescribed by law, i.e. by using the appropriate form. It is essential, in this legal procedure, to respect the best interests of the child.

The principle of the best interests of the child is gaining increasing attention among lawyers, public authorities, and the courts in dealing with children. However, at the constitutional level, the definition of "the best interests of the child" is not enshrined. Moreover, the legislation of Ukraine uses different names for this legal category "best interests" and "highest interests", and the courts, in turn, differently protect the rights and interests at their discretion.

It is worth noting that the current approach to resolving family disputes involving a child is changing. The above issues are quite relevant today, as a third of civil cases arise from family relationships that directly or potentially affect the interests of children. Therefore, it is necessary to explore the basic principles of the concept of ensuring the "best interests of the child" under international law and national law with an approach to their reproduction through the prism of national jurisprudence.

Given the ambiguity of interpretation and the lack of normative definition of the interpretation of children's rights, it is mostly the prerogative of courts to consider family disputes on children's interests, it is major to analyze the constitutional principles of the family several supranational судами. Аналіз актуальної судової практики, в тому числі практики ЄСПЛ дав змогу зробити висновок, що сьогодні суди та інші компетентні органи значну увагу приділяють аналізу “як дитині буде краще” і приймають обгрунтовані рішення, та за необхідності виправляючи попередньо допущені помилки.

Ключові слова: конституційні засади, цивільне судочинство, права та інтереси, дитина, сімейні права та інтереси.

regulations. In addition, it is meaningful to study the mechanisms of protection of the rights and interests of the child in civil proceedings and analyze existing problems in litigation in terms of compliance with the interests of the child and develop proposals to improve legislation and jurisprudence to improve the protection of rights and interests of the child in civil proceedings.

The object of the study is the constitutional principles of safety of family rights and interests of the child in civil proceedings. The subject of the study is the social relations that arise, change, and end during the protection of the rights and interests of the child in civil proceedings.

Theoretical Framework or Literature Review The main issue of this article was studied by: Evko (2018), Kravchuk (2017), Loboyko and Shilo (2015), Luspenik (2018), Nekrasova (2013), Olkhova (2013), Petrochko (2014), Stoyanova (2015), and Tuboltseva (2018).

Thus, Evko (2018) researched the peculiarities of judicial protection of family rights and drew attention to problematic aspects of civil law and process. The author's research reveals the peculiarities of litigation arising from family disputes. The author made a comparative legal analysis of family and civil procedural law. The result of this analysis was the author's conclusion that in the judicial protection of family rights, although there are dispositive principles, but the implementation of the subjects of family law dispositive principles in civil proceedings in protecting their violated family rights and legitimate interests has limited application compared to others. categories of civil cases. Also, the researcher stressed that the specifics of judicial protection of family rights depend on the specifics of family relationships, which have a strong personal character, but their protection is one of the tasks of the Ukrainian state. Based on this, in the judicial protection of family rights, although there are dispositive principles, the 


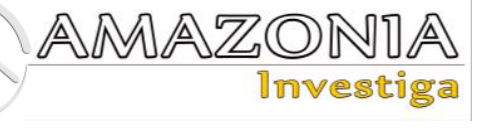

implementation of the subjects of family law dispositive principles in civil proceedings in the protection of their violated family rights and legitimate interests has limited application compared to other categories of civil cases.

Another researcher, Kravchuk (2017), studied in detail the concept of "the best interests of the child" in Russian family law. The author explored both problematic aspects of ensuring rights and conducted an analysis of international experience.

Petrochko (2014) studied the notion of "the best interests of the child", their essence, and ways of providing given the Ukrainian experience.

The concept of judicial law in the context of judicial protection of rights and freedoms has been the subject of research by scholars such as Loboyko and Shilo (2015). In their work, the authors considered the controversial issues of the concept of judicial law, which is based on judicial protection of human rights and freedoms, and concluded that judicial law is not a branch of law because it does not have a specific subject of legal regulation. In particular, the authors considered the normative and practical value of the concept of judicial law as a source of new scientific knowledge on the convergence of theoretical and unification of regulations of the judiciary. The approaches developed by the authors were used in our study.

In his work, Luspenik (2018) examined exactly what and how the novelties of the civil process influenced judicial practice. Thus, the author analyzed in detail the features of the changes in 2016 to civil procedural law. For example, the author drew attention to a novelty in the evidentiary procedure, according to which copies of evidence (except physical evidence) introduced to the court are sent in advance or provided by the person submitting them to other participants in the case. In particular, he noted that Article 191 of the Civil Procedure Code (Law No. 1618-IV, 2004), devoted to sending copies of the statement of claim and the documents attached to it, does not specify the procedure for sending participants copies of electronic evidence. Thus, in civil proceedings there is a permissive nature of legal regulation, ie the subjects of civil procedural legal relations can perform only those actions that are expressly permitted by law. Therefore, in order not to cause problems in practice, it is necessary to clearly define which rule of procedural law is special and which is general. Another conclusion that follows from Part 9 of Article 84 of the Civil

Procedure Code - public availability of information eliminates the need to provide the parties with a copy of the evidence. As can be seen from the literal interpretation, this is not public information, which is determined by the law "On access to public information", but any publicly available information. The law does not define what public access is, so in this context, the question of the use of information from the Internet naturally arises, one of the most important features of which is its public availability. In the context of the interpretation of this article of the CPC, the author considers it appropriate to be exempt from the obligation to submit copies of evidence containing information available on the official websites of state and local governments, other reputable institutions, unified state electronic registers. Therefore, the author concluded that the procedures for submitting electronic evidence need further legislative refinement in order not to complicate their use in practice.

But Nekrasova (2013) studied the ways to ensure safety for the rights and interests in family and civil law, conducting a detailed analysis of them.

Based on international experience, Olkhova (2013) analyzed the principle of the best interests of the child in international humanitarian law.

Stoyanova (2015) examined the impact of certain provisions of the European Convention on Adoption in courts' consideration of adoption cases. At the same time, Tuboltseva (2018) paid more attention to ensuring the best interests of the child when the court considers adoption cases.

An important study was conducted by Churpita (2016), who analyzed in detail the conceptual principles of protection of family rights and interests in non-litigious civil proceedings.

From the above analysis of the literature, it can be summed up that the principles of protection of family rights and interests of the child have been the subject of research, but in civil proceedings this issue are insufficiently studied.

\section{Methodology}

During the study, the hermeneutic method was used to interpret the concept of "best interests of the child." With the help of system-structural and structural-functional methods, it became possible to reveal the relationship between the elements of the mechanism of judicial protection of children's rights and mechanisms of out-of-court 
protection. The historical-legal aspect helped to understand the chronology of the development of legislation on family rights, its qualitative changes, and to determine the factors that influenced the development of legislation. Moreover, the use of historical and legal methods allowed to trace the evolution of legal regulation, and to explore the genesis of scientific views on the protection of family rights and interests in civil proceedings.

The comparative-legal method played an equally important role in conducting this study. This method was used to determine the place of the studied issue in different countries. Hence, the identification of the general and special constitutional principles of judicial safety in civil proceedings of the studied issue in domestic and foreign civil procedural law, as well as when comparing scientific views on the outlined issues.

A necessary role in the study was also played by the method of theoretical modeling in the analysis of social relations and their possible transformations because thanks to this method, it became possible to study potential changes in the context of judicial protection of children's rights.

Formal and logical methods (analysis and synthesis, induction and deduction, proof and refutation, comparison, generalization, etc.) helped to explore the specifics of protecting the family rights and interests of the child in civil proceedings. The induction and deduction helped to analyze the features of the relevant cases by the courts. The formal-logical method has traditionally become important in family law. He allowed the logical application of regulations, rules, and forms of law to individual situations. The system-structural method in the conditions of the rule of law permits applying the law from the standpoint of justice. The formal-logical method is used in the construction of classifications in science, provides an opportunity to further identify the features of individual legal phenomena, their legal nature. The formal-logical method provided an opportunity to periodize phenomena and formulate the content of legal categories according to their characteristics. In addition, this method allowed to identify other existing norms from the existing norms. With the help of induction, the general norm (principle) for the protection of family rights, in general, was derived from the norm that applies to all cases of protection of family rights of children. That is, in this regard, the general rules of law are like ready-made material for deductive work: studying the content of the law, it became possible to draw logical conclusions, develop its general concepts and provisions and build on this basis a system of general principles of protection of children's rights. Both the inductive method and deduction were used in this study to systematize the empirical material to more accurately and consistently formulate the conclusions drawn from the study of the peculiarities of civil proceedings for the protection of children's rights.

\section{Results and Discussion}

Before considering the constitutional principles of safety of family rights and interests of the child in civil proceedings, let us consider the legal nature of subjective family rights and legally protected family interests as an object of protection in civil proceedings.

Subjective family law - type and measure of possible and permissible behavior of the subject of family relations, which consists of the right to perform their actions; authority to demand certain actions from the obligated party; the right to apply to the relevant authorities for protection of their violated, unrecognized or disputed right.

The family interest protected by law is the need and desire to use specific material and (or) intangible benefits, which may or may not be mediated by certain subjective family rights.

Given the relationship between subjective family law and the legally protected family interest, we can conclude that the latter, reflected in the minds of the entitled subject, is a meaningful factor in his volitional behavior, and subjective family law - a special legal means of private goals and, thus, protected by law (legitimate) family interest.

Subjective family rights and legally protected (legitimate) family interests, which are subject to protection in civil proceedings, can be divided according to the subjective composition of their bearers into:

a) subjective family rights and legally protected (legitimate) family interests, which are held by the spouses;

b) subjective family rights and legally protected (legitimate) family interests, which are held by parents and children, and;

c) subjective family rights and legally protected (legitimate) family interests, the bearers of which are the subjects. 


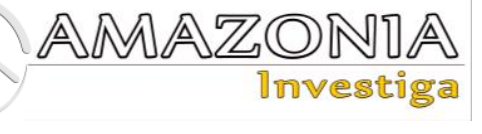

The legal development of the studied issue in civil proceedings can be explored through the following chronology of the adoption of regulations.

One of the most essential documents regulating the rights of the child is the Convention for the Protection of Human Rights and Fundamental Freedoms and the 1989 UN Convention on the Rights of the Child (United Nations, 1989).

Article 3 of the UN Convention on the Rights of the Child stipulates that in all actions concerning children, whether public or private, social security, courts, administrative or legislative bodies, the best interests of the child shall be a primary consideration. States Parties that recognize or permit the adoption of the adoption system shall ensure that the best interests of the child are a primary consideration (United Nations, 1950; United Nations, 1989).

Given the important role of protecting the rights of the child, attention should be paid to the interpretation of the principle of the best interests of the child. At the declarative level, the best interests of the child are taken into account in the administration of justice following the Guidelines of the Committee of Ministers on Child-Friendly Justice, adopted by the Committee of Ministers on 17 November 2010 at the 1098th meeting of the Ministers' Instruments. adaptation by States Parties to their judicial and extrajudicial systems to the specific rights, interests, and needs of children. The Guiding Principles are based on the principles enshrined in international instruments, as well as the caselaw of the European Court of Human Rights. Among the highlighted fundamental principles of child justice, such as honor, dignity, protection against discrimination, and the rule of law, is the principle of the best interests of the child. Thus, member states must ensure that the rights of the child to the best interests of the child are exercised as a primary consideration in all matters affecting or affecting them (Committee of Ministers of the Council of Europe, 2010).

Therefore, the Guidelines state that when considering cases, the views and views of children must be duly taken into account when assessing the interests of children who are involved in or will be affected by the trial; all relevant authorities should take an integrated approach to take into account all interests that may be at stake, including psychological and physical health, legitimate, social, economic interests of the child.
At the constitutional level in Ukraine, the rights of children are enshrined, for example, Art. 51 of the Constitution of Ukraine proclaims the protection of childhood, equality of rights of children regardless of origin, prohibition of violence against children and their exploitation, protection and assistance of the state to a child deprived of the family environment (Law No. 254k/96-VR, 1996). Simultaneously, no article of the Constitution of Ukraine establishes age restrictions for the exercise of rights and freedoms and the performance of duties and does not contain a direct reference to the peculiarities of their implementation by the child.

No less significant act regulating the rights of the child is the Law No. 2947-III (2002), which establishes the principle of observance of the highest interests of the child. As a result of the analysis of norms of the Family Code of Ukraine it is possible to allocate classification of forms of protection of family rights, depending on the subject of protection:

Forms of protection of family rights

- court;

- guardianship and custody bodies;

- notary bodies (does not apply to personal non-property rights), and;

- $\quad$ in the form of self-defense.

Additionally, we consider it more appropriate to divide into jurisdictional and non-jurisdictional forms of protection of rights and interests.

The No. 2402-III (2001) states that the protection of children in Ukraine is a strategic national priority, which is important for the national security of Ukraine, the effectiveness of the domestic policy, and to ensure the realization of children's rights to life, health, education, social protection, comprehensive development and upbringing in a family environment establishes the basic principles of state policy in this area, based on ensuring the best interests of the child (Law No. 2402-III, 2001).

The Civil Procedure Code of Ukraine provides a general list of issues that need to be identified to decide on, for example, adoption, but we believe that more detailed attention of the court in considering and deciding the case should be paid to the circumstances that determine the legal grounds for adoption. Thus, the subject of judicial activity is to verify the grounds for adoption, the compliance of such adoption to the interests of the person to ensure stable and 
harmonious living conditions (Law No. 1618-IV, 2004).

In deciding the merits of the application, the court is obliged to check: the consent of the child's parents to the adoption (if necessary); the applicant's ability to be an adoptive parent; whether the child is the subject of adoption following the law and whether the requirements of family law regarding the consent of the child are met; whether the conclusions of the guardianship authority and the adoption permit of the authorized body of executive power meet the necessary requirements (Law No. 1618-IV, 2004).

Therefore, the law establishes the obligation to observe the best interests of the child, but unfortunately, there is no normative definition of this concept. Given this circumstance, the body that most often deals with the notion of the best interests of children assesses the degree of observance of these interests in civil proceedings is the court.

For a clearer approach of the courts, let's analyze the approaches of the European Court of Human Rights (hereinafter - EctHR) to the protection of children's rights.

One of the most discussed and applied decisions of the European Court of Human Rights is the decision in the case of M.S. v. Ukraine (application no. 2091/13) of 11 July 2017 (Judgment No. 2091/13, 2017). In this judgment, the ECtHR found a violation of Art. 8 of the Convention and stressed the need to take into account the best interests of the child, which take precedence over the interests of parents. Determining the best interests of the child requires a detailed study of the situation, taking into account various factors that may affect the interests of the child, following a fair procedure in resolving the dispute for all parties. Thus, in paragraph 75 of the judgment, in this case, the ECtHR noted that there is a broad consensus today, including in international law, to support the idea that in all decisions concerning children, the best interests of the child should be a primary consideration. The best interests of the child, depending on their nature and seriousness, may exceed the interests of the parents. The same ECtHR stated in paragraph 54 of the judgment in Hunt v. Ukraine (application no. 31111/04) of 7 December 2006 (Judgment No. 31111/04, 2006).

To understand the guidelines for the protection of family rights in civil proceedings, let us consider some legal positions of the Supreme Court on the interpretation of the best interests of the child and the application of this principle in family matters.

In its decision in case № 712/10623/17 of 4 July 2018, the Grand Chamber of the Supreme Court stated that the provision on equal rights and responsibilities of parents in the upbringing of a child cannot be interpreted to the detriment of the interests of the child. Each case requires a detailed study of the situation, taking into account various factors that may affect the interests of the child, including his opinion, if he is able to formulate their own views according to age (Case No. 712/10623/17, 2018).

In this case, the father did not give the child consent to go abroad to study. The child's mother filed a lawsuit in court to obtain permission for the child to travel abroad without the consent and support of the father based on a court decision for the time of the child's education. The father objected to the lawsuit and said that the mother's claim contradicts current legislation, which determines the equality of rights and responsibilities of parents in raising a child, and this may lead to the actual deprivation of the child's father of the opportunity to participate in her upbringing and communication with her/him. The courts of three instances have determined that the child's departure abroad for the purpose of study and education is in his best interests. Therefore, the rights of the child must take precedence over the rights of the father. Based on the above, the mother's claim was satisfied.

The same approach is traced in the decision of the Civil Court of Cassation in case № 534/1578/18 of 18 March 2020 (Case No. 534/1578/18, 2020). The said decision states that the analysis of the rules of law and practice of the ECtHR gives grounds to conclude that equality of parental rights is derived from the rights and interests of the child for the harmonious development and proper upbringing, first of all, the interests of the child in a situation of the dispute must be determined, and only then the rights of parents. Any disputes between the parents in which the child is involved and which are resolved by the guardianship authority or the court, harm its physical and mental development and contradict the principle of ensuring the best interests of the child.

In the decision in case No. 372/3324/17 of April 14, 2020, the Civil Court of Cassation noted that the child is the most vulnerable party in any family conflict, and litigation of family disputes affecting the interests of the child is particularly difficult. The child is a subject of law and 


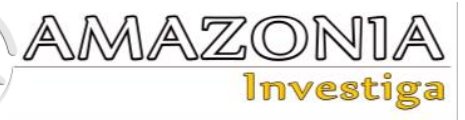

(despite his minor age and incomplete civil capacity) has a certain amount of rights. One of her basic rights is the right to express her opinion and the right to have her opinion taken into account in matters concerning her life (Case No. 372/3324/17, 2020).

The above shows that the Supreme Court, in its consideration, seeks to thoroughly and fairly assess the circumstances of the case, based on the analysis to determine what is in the best interests of children and make informed decisions, if necessary, correcting errors made by previous courts.

\section{Conclusions}

1. The content of the concept of "best interests of the child" and its normative consolidation in national and international law are analyzed. The national case law on the application and interpretation of the principle of the best interests of the child in family matters is analyzed and the conclusion is made on the need to amend the national legal framework to form a single case law on children's rights.

2. It is determined that the safuty of family rights and legally protected interests is the most significant guarantees for the existence of these rights and interests. This is since the rights and interests in any sphere of public life are not always exercised without hindrance.

3. It is investigated that, in the theory of law, there are different approaches of scientists to the selection of forms of protection of family rights. We consider the most appropriate division into jurisdictional and nonjurisdictional protection.

4. The analysis of the current practice of the ECtHR and the Supreme Court gives grounds to assert that at the level of courts there is a correct and detailed understanding of the principle of the best interests of the child, which does not contradict the provisions of international instruments. Simultaneously, making the necessary changes to the legislation will ensure the correct application of this principle by lower courts, guardianship authorities, and other state bodies that make decisions in cases concerning children.

Regarding further research, it is necessary to examine in more detail the international experience in regulating "family" litigation to implement the best foreign experience in countries that are just beginning to protect the rights of children.

\section{Bibliographic references}

Churpita, G. (2016). Conceptual principles of protection of family rights and interests in non-litigious civil proceedings (doctoral thesis). National Academy of Internal Affairs of the Ministry of Internal Affairs of Ukraine, Kyiv. Recovered from http://idpnan.org.ua/files/churpita-g.v.kontseptualni-zasadi-zahistu-simeynih-pravta-interesiv-u-poryadku-nepozovnogotsivilnogo-sudochinstva-_a_.pdf

Committee of Ministers of the Council of Europe. (2010). Guidelines of the on childfriendly justice. Recovered from https://rm.coe.int/16804c2188.

Case of M.S. v. Ukraine, Application № 2091/13. Decision of the European Court of Human Rights, 11 July 2017. Recovered from https://hudoc.echr.coe.int/eng\#\{\%22fulltext \%22:[\%22M.S.\%20v.\%20Ukraine\%20(no. $\% 202091 / 13) \% 22], \% 22$ documentcollectioni d2\%22:[\%22GRANDCHAMBER $\% 22, \% 22$ CHAMBER\%22],\%22itemid\%22:[\%22001$175140 \% 22]\}$

Case of Hunt v. Ukraine, Application № 31111/04. Decision of the European Court of Human Rights, 7 December 2006. Recovered from

https://hudoc.echr.coe.int/eng\#\{\%22itemid\% 22:[\%22001-78410\%22]\}.

Case No. 372/3324/17. (Unified register of court decisions of Ukraine, April 14, 2020). Retrieved January 18, 2022, from http://reyestr.court.gov.ua/Review/88815291

Case No. 534/1578/18. (Unified register of court decisions of Ukraine, March 18, 2020). Retrieved January 18, 2022, from http://reyestr.court.gov.ua/Review/88376149

Case No. 712/10623/17. (Unified register of court decisions of Ukraine, July 4, 2018). Retrieved January 18, 2022, from http://reyestr.court.gov.ua/Review/75266002

Evko, V. (2018). Features of judicial protection of family rights. Problems of civil law and process. Kharkiv: KhNUVS. Recovered from http://dspace.univd.edu.ua/xmlui/handle/123 456789/4725

Kravchuk, N. (2017). "The best interests of the child": the content of the concept and its place in the family legislation of Russia. Actual problems of Russian law, 5(78), 97-103. Recovered from https://aprp.msal.ru/jour/article/view/493?lo cale=ru_RU 
Law No. 1618-IV, Civil Procedure Code of Ukraine. The Verkhovna Rada of Ukraine, Kyiv, 2004. Recovered from https://zakon.rada.gov.ua/laws/show/161815\#Text

Law No. 2402-III, On the protection of childhood. The Verkhovna Rada of Ukraine, Kyiv, 2001. Recovered from https://zakon.rada.gov.ua/laws/ show/240214.

Law No. 254k/96-VR, Constitution of Ukraine. The Verkhovna Rada of Ukraine, Kyiv, of June 28, 1996. Recovered from https://zakon.rada.gov.ua/laws/show/254\%D 0\%BA/96-\%D0\%B2\%D1\%80\#Text

Law No. 2947-III, Family Code of Ukraine. The Verkhovna Rada of Ukraine, Kyiv, 2002. Recovered from https://zakon.rada.gov.ua/laws/ show/294714.

Loboyko, L., \& Shilo, O. (2015). The concept of judicial law in the context of judicial protection of rights and freedoms. Law of Ukraine, 3, 60-70. Recovered from https://pravoua.com.ua/ua/store/pravoukr/pra voukr_3_15/Loboiko-Shylo_3_15/

Luspenik, D. (2018). What exactly and how the novelties of the civil process influenced the judicial practice. Law and business. Recovered from https://zib.com.ua/ua/134331.html

Nekrasova, O. (2013). Ways to protect the rights and interests in family and civil law: a comparative aspect. Bulletin of the Bar Academy of Ukraine, 2(27), 35-38.
Recovered

from http://nbuv.gov.ua/UJRN/vaau_2013_2_8

Olkhova, A. (2013). The principle of the best interests of the child in international humanitarian law. Journal of Kyiv University of Law, 1, 348-352. Recovered from http://nbuv.gov.ua/UJRN/Chkup_2013_1_84

Petrochko, Zh. (2014). The best interests of the child: the essence and ways of providing. "Scientific Notes" of Nizhyn State University of M. Gogol. Psychological and pedagogical sciences, 3, 70-74. Recovered from http://nbuv.gov.ua/UJRN/Nzspp_2014_3_13

Stoyanova, T. (2015). Analysis of the impact of certain provisions of the European Convention on Adoption in courts' adoption cases. Pravova Derzhava, 21, 159-162. Recovered from http://dspace.onua.edu.ua/bitstream/handle/1 $1300 / 5758 /$ Stoyanova.pdf? sequence $=1 \&$ isAl lowed $=\mathrm{y}$.

Tuboltseva, Ya. (2018). Ensuring the best interests of the child in court adoption cases. Theory and practice of jurisprudence, 2(14), 1-14. Recovered from http://nbuv.gov.ua/UJRN/tipp_2018_2_9

United Nations. (1950). Convention for the Protection of Human Rights and Fundamental Freedoms. Recovered from https://www.echr.coe.int/documents/convent ion_eng.pdf

United Nations. (1989). Convention on the Rights of the Child. Recovered from https://www.ohchr.org/en/professionalintere st/pages/crc.aspx 